\title{
Broadly neutralizing antibodies: What is needed to move from a rare event in HIV-1 infection to vaccine efficacy?
}

\author{
Harini Subbaraman, Merle Schanz and Alexandra Trkola* (D)
}

\begin{abstract}
The elicitation of broadly neutralizing antibodies (bnAbs) is considered crucial for an effective, preventive HIV-1 vaccine. Led by the discovery of a new generation of potent bnAbs, the field has significantly advanced over the past decade. There is a wealth of knowledge about the development of bnAbs in natural infection, their specificity, potency, breadth and function. Yet, devising immunogens and vaccination regimens that evoke bnAb responses has not been successful. Where are the roadblocks in their development? What can we learn from natural infection, where bnAb induction is possible but rare? Herein, we will reflect on key discoveries and discuss open questions that may bear crucial insights needed to move towards creating effective bnAb vaccines.
\end{abstract}

\section{Background}

The potency of the neutralization response to HIV-1 has long been underappreciated, as most of the antibodies identified were type-specific or had only limited breadth [1]. This only changed in the early 2000 s, with the discovery of the new classes of potent bnAbs $[1,2]$. This positioned bnAb responses as the major goal of vaccine development and in prevention. Despite their potency and breadth, there is no evidence that bnAbs ameliorate disease progression in natural infection, as they are subject to viral escape like any autologous neutralization activity [3-6]. Application of bnAbs as a therapeutic vaccine in established infection is therefore limited to settings where activity over shorter intervals is required. This is similar to what has been discussed in treatment combinations that aim to eliminate the latent HIV-1 reservoir [7]. In prevention, where bnAbs are considered both as a passively administered drug and are intended to be elicited by vaccines, their potential is obvious and has been underscored by numerous animal studies [ 1 , $2,8]$. The virus inoculum that needs to be combatted to prevent transmission is low [9]. bnAbs have a window of opportunity to prevent infection in the absence of

*Correspondence: trkola.alexandra@virology.uzh.ch Institute of Medical Virology, University of Zurich, Zurich, Switzerland an established cellular HIV reservoir and potentially in concert with effector functions of the immune system. However, challenges for the use of bnAbs for prevention remain high. Therapeutically, bnAbs could be selectively applied to patients harboring sensitive strains. In contrast, antibodies elicited by a vaccine and/or used in a prevention setting must be highly potent and have exceptional breadth, targeting a wide spectrum of globally circulating HIV-1 strains.

Discoveries in the last decade have revealed that such elite neutralizing responses occur during natural infection, but are rare [10-14]. Initial hopes that delineation of the epitopes of identified elite bnAbs would allow rapid construction of matching immunogens were not fulfilled. Reverse vaccinology and structure-guided immunogen design based on these elite bnAbs brought much momentum to the field. The most recently developed immunogens are the first that induce Tier-2 neutralizing activity, but none of them has evoked a bnAb response to date $[15,16]$. Therefore, natural infection remains the only system in which we can decipher the parameters that drive the evolution of bnAbs. Herein, we review key observations made on the determinants of bnAb development by studying both individual bnAb donors and HIV-1 patient cohorts and mark open questions that need to be addressed. 


\section{The complex interrelation of bnAb maturation and virus escape}

Focused efforts to decipher antibody maturation pathways alongside virus evolution have facilitated reconstruction of bnAb development in some individuals $[3,4$, 17-23]. It is generally appreciated that a complex interplay between escape virus and $\mathrm{Ab}$ response is needed to trigger bnAb evolution [22]. The role of virus diversification, including superinfection, which can precede the emergence of breadth, has been underscored in several studies [3, 5, 20, 22, 24-27]. Whether virus diversification is driving or is, in fact, a consequence of bnAb development remains difficult to dissect, as Env variability also increases in response to bnAb pressure [28-31]. This iterative and circular nature of virus and antibody co-evolution that occurs in natural infection will be difficult to mimic by vaccination. Deciphering cause and consequence, as well as defining minimal necessary components of bnAb development will be key for designing successful vaccine regimens.

Prolonged bnAb maturation does not necessarily lead to improved breadth. The highest frequency of bnAb activity is observed after approximately 3 years of infection [12, 14, 32-34]. However, further prolonged replication does not increase frequencies [12, 14, 32, 33] and can even lead to a decrease or loss of bnAb activity [20]. Hence, while a relatively long exposure to viral antigen is commonly needed in adult HIV-1 infection to mount bnAb responses, continued adaptation of early bnAbs can also lead to "off-track" antibodies that lack breadth but have increased autologous strain specificity [3, 17, 22, 35]. Likewise, continued somatic hypermutation (SHM) will always generate "dead-end" antibodies harboring mutations that impede further development of functional antibodies [3, 17, 36]. SHM observed in isolated bnAbs often includes mutations not required for breadth development [37]. Short bnAb maturation phases with targeted breadth evolution must therefore be an ultimate goal for vaccine design.

Virus escape creates new epitopes that allow bnAb responses to mature $[5,24]$. Slow virus escape may be beneficial for bnAb development, as this prolongs exposure to the bnAb-sensitive epitope, thereby extending antigenic stimulation and increasing chances of bnAb maturation [38-40]. Along these lines, partial evasion of virus from bnAbs, as can occur during cell-cell transmission [38, 41-43], allows the bnAb-sensitive virus to persist, ensuring sustained epitope presentation to the maturing antibody.

The virus population is not only shaped by the bnAb lineage, but is also subject to pressure of the vigorous type-specific antibody response each patient mounts. This can, in turn, substantially impact bnAb evolution.
Early bnAb development may be compromised through competitive exclusion by strain-specific antibodies that target the same epitope [44, 45]. Yet, cooperation between different antibody lineages may also facilitate bnAb development by driving the virus into escape mutations that prevent full escape from bnAb lineages [18, $19,40]$. Antibody helper lineages can be strictly strainspecific [40] or mature into bnAbs [19]. Understanding whether the development of multiple bnAb lineages [5] and bnAb/helper [18] tandems are common or rare events will be essential to appreciate (1) their importance and (2) the need to incorporate similar help into vaccination strategies. Of note, recent reports have suggested that passively administered bnAbs may perform antibody helper functions. Therapeutic administration of the bnAb 3BNC117 to viremic individuals enhanced heterologous plasma neutralization breadth beyond escape to 3BNC117 [46]. Passive immunization of newborn macaques with nAbs at sub-neutralizing doses before oral SHIV challenge led to rapid elicitation of an autologous neutralization response and early control of viremia [47].

\section{Factors that drive bnAb development}

A range of factors that promote bnAb development has been implicated and several confirmed across different cohorts [6, 11, 12, 14, 32, 33, 48-50] (Tables 1, 2 and Fig. 1). These studies highlight that a combination of partly interdependent factors, which are linked with disease progression, direct bnAb development. Several prominent drivers of bnAb development are linked to persistent antigenic stimulation. The independent impact of viral load, infection length and diversity on bnAb frequency has been demonstrated [12, 14, 33, 48, 49]. These factors act in concert to ensure consistent antigenic stimulation. High viral load was the factor most consistently found to positively influence neutralization breadth across cohorts [6, 11, 12, 14, 32, 33, 48-51]. However, while rates of bnAb activity are significantly higher amongst individuals with high viral load, breadth can also develop in HIV-1 controllers, although commonly at lower frequency [11,34, 39, 51-53]. Thus, high antigen loads promote bnAb evolution but are certainly not the sole driving force.

Two other parameters linked to extended antigenic stimulation, virus diversity and length of infection, also increase the likelihood of bnAb elicitation [11, 12, 14, 48, 49]. This highlights that exposure to antigen over prolonged periods of time aids bnAb evolution. Env diversification inevitably increases during protracted infection, which is mostly driven by the consecutive rounds of $\mathrm{Ab}$ maturation and virus escape. Env diversity must therefore be viewed as both cause and consequence of neutralizing 
Table 1 Overview of patient cohort studies investigating viral and disease factors linked with bnAb development

\begin{tabular}{|c|c|c|c|c|}
\hline Reference & $\begin{array}{l}\text { Number } \\
\text { of subjects }^{a}\end{array}$ & $\begin{array}{l}\text { Investigated viral } \\
\text { and disease factors }\end{array}$ & Association with breadth & Additional information on investigated parameter \\
\hline \multirow[t]{5}{*}{ Doria-Rose et al. [11] } & 103 & Viralload & Positive & Contemporaneous \\
\hline & & Infection duration & None & \\
\hline & & Transmission mode & None & \\
\hline & & CD4+ T cell levels & None & Contemporaneous \\
\hline & & History of ART use & None & \\
\hline \multirow[t]{3}{*}{ Euler et al. [6] } & 82 & Viralload & Positive & Set point \\
\hline & & CD4+ T cell levels & Negative & Set point \\
\hline & & Disease progression & None & \\
\hline \multirow[t]{3}{*}{ Gray et al. [33] } & 40 & Viralload & Positive & Set point \\
\hline & & CD4+ T cell levels & Negative & 6 months post-infection \\
\hline & & CD4+ T cell decline & Positive & Difference between levels pre-infection and at 6 months \\
\hline \multirow[t]{5}{*}{ Landais et al. [14] } & 439 & Viral load & Positive & Set point \\
\hline & & Infecting subtype & Positive & Subtype C infection \\
\hline & & Infection duration & Positive & \\
\hline & & Transmission mode & None & \\
\hline & & CD4+ T cell levels & Negative & All tested time points beyond 6 months post-infection \\
\hline Mikkell et al. [32] & 38 & Viralload & Positive & Contemporaneous \\
\hline \multirow[t]{4}{*}{ Piantadosi et al. [48] } & 70 & Viralload & Positive & Set point \\
\hline & & Viral diversity & Positive & Env \\
\hline & & CD4+ T cell levels & None & Contemporaneous \\
\hline & & Disease progression & None & \\
\hline \multirow[t]{6}{*}{ Rusert et al. [12] } & 4484 & Viralload & Positive & Contemporaneous \\
\hline & & Viral diversity & Positive & Pol \\
\hline & & Infecting subtype & None & \\
\hline & & Infection duration & Positive & \\
\hline & & Transmission mode & Weakly positive & Modestly higher bnAb activity in IDUs \\
\hline & & CD4+ T cell levels & Weakly positive & $\begin{array}{l}\text { Contemporaneous; modest association with cross- } \\
\text { neutralization activity }\end{array}$ \\
\hline \multirow[t]{3}{*}{ Sather et al. [49] } & 39 & Viralload & Positive & Average of all tested time points \\
\hline & & Infection duration & Positive & \\
\hline & & CD4+ T cell levels & None & Average of all tested time points \\
\hline \multirow[t]{2}{*}{ van Gils et al. [50] } & 35 & Viral load & Positive & Set point \\
\hline & & CD4+ T cell levels & Negative & Set point \\
\hline
\end{tabular}

a Indicates total number of subjects included. Specific analyses may have been carried out on subsets of these numbers

antibody maturation. Emerging escape variants may generate new epitopes on Env that engage novel antibody germlines and start a bnAb lineage, as demonstrated for individual donors [5, 24]. The presence of multiple transmitted founder $(\mathrm{T} / \mathrm{F})$ viruses as reported for intravenous drug users (IDUs), as well as in superinfection, similarly expose the immune system to high Env diversity. In a recent large cohort study, IDUs showed modestly higher frequency of bnAb activity $[12,54]$. Whether this is a result of higher diversity or other factors intrinsic to HIV infection of IDUs remains to be determined. Env diversity has been postulated as a driver of bnAb activity in cases of superinfection [3, 20, 25-27]. Nevertheless, superinfection does not guarantee the development of bnAb activity, as recent studies revealed $[55,56]$. Diversity may have a dual role in bnAb development. Highly diverse Env populations may have an increased chance to harbor a specific Env variant that is capable of initiating a bnAb lineage. Continuously increasing Env diversity, on the other hand, provides a means to support bnAb maturation by presenting multiple antigenic variants.

\section{The impact of the infecting virus}

As evidenced by the unresolved impact of viral diversity in steering bnAb responses, the overall role of the infecting virus remains to be defined. What are the genetic 
Table 2 Overview of patient cohort studies investigating host and immune factors linked with bnAb development

\begin{tabular}{|c|c|c|c|}
\hline Reference & $\begin{array}{l}\text { Number } \\
\text { of subjects }^{a}\end{array}$ & Investigated host and immune factors & Association with breadth \\
\hline \multirow[t]{6}{*}{ Boliar et al. [90] } & 41 & Total plasma lgG & Positive \\
\hline & & B cell expression of: & \\
\hline & & PD-1 & None \\
\hline & & BTLA & None \\
\hline & & Ki67 & None \\
\hline & & CD95 & None \\
\hline \multirow[t]{14}{*}{ Cohen et al. [78] } & 15 & CXCR5 ${ }^{+} \mathrm{CD} 4^{+} T$ cells & Positive \\
\hline & & CXCR5 ${ }^{+} P D-1^{+} C D 4^{+} T$ cells & Positive \\
\hline & & CXCR5 ${ }^{+} P D-1^{+} / \mathrm{COS}^{+} \mathrm{CD} 4^{+} T$ cells & Positive \\
\hline & & Plasma CXCL13 & Positive \\
\hline & & Plasma IL21 & None \\
\hline & & Plasma BAFF & None \\
\hline & & Other cytokines and chemokines & None \\
\hline & & $\mathrm{CD}^{-}{ }^{-} \mathrm{CD} 19^{+} \mathrm{CD}^{2} 7^{-}$naïve $\mathrm{B}$ cells & None \\
\hline & & $\mathrm{CD}^{-}{ }^{-} \mathrm{CD} 19^{+} \mathrm{CD}_{2} 7^{+}$memory $\mathrm{B}$ cells & None \\
\hline & & $\begin{array}{l}\text { Env-specific } \mathrm{CD}^{-}{ }^{-} \mathrm{CD} 19^{+} \mathrm{CD}_{2} 7^{+} \mathrm{gp}_{120^{+}} \text {memory } \mathrm{B} \\
\text { cells }\end{array}$ & None \\
\hline & & CXCR5 expression on B cells & None \\
\hline & & Expression of activation-associated genes & Positive \\
\hline & & Expression of IFN-stimulated genes IFI27 and ISG15 & Positive \\
\hline & & Expression of CXCL13 and RGS13 & Positive \\
\hline \multirow[t]{5}{*}{ Doria-Rose et al. [51] } & 148 & Total CD19+B cells & None \\
\hline & & $\mathrm{CD}_{19} \mathrm{lgG}^{+} \mathrm{B}$ cells & None \\
\hline & & $\mathrm{CD} 19^{+} \mathrm{CD} 27^{+}$memory B cells & None \\
\hline & & $\mathrm{CD} 19^{+} \mathrm{CD} 20^{-} \mathrm{CD} 27^{+++} \mathrm{CD} 38^{+++}$plasmablasts & None \\
\hline & & Env-specific CD19+ gp $140^{+}$B cells & None \\
\hline \multirow[t]{4}{*}{ Doria-Rose et al. [11] } & 103 & Ethnicity & None \\
\hline & & Gender & None \\
\hline & & Age & None \\
\hline & & HLA genotype & None \\
\hline \multirow[t]{6}{*}{ Dugast et al. [53] } & 163 & Plasma CXCL13 & Positive \\
\hline & & PlasmasCD4OL & Positive \\
\hline & & Plasma RANTES & Positive \\
\hline & & PlasmaTNF-a & Positive \\
\hline & & Plasma IP-10 & Positive \\
\hline & & Other cytokines and chemokines & None \\
\hline Havenar-Daughton et al. [81] & 228 & Plasma CXCL13 & Positive \\
\hline \multirow[t]{5}{*}{ Kadelka et al. [54] } & 4281 & $\lg G 1, \lg G 2$ and $\lg G 3$ binding to trimeric Env & Positive \\
\hline & & IgG1 binding to Env-gp120 & Positive \\
\hline & & IgG2 binding to Env-gp 120 & Positive \\
\hline & & IgG3 binding to MPER & Positive \\
\hline & & lgG3 binding to $p 17$ and $p 24$ & Positive \\
\hline
\end{tabular}


Table 2 (continued)

\begin{tabular}{|c|c|c|c|}
\hline Reference & $\begin{array}{l}\text { Number } \\
\text { of subjects }^{a}\end{array}$ & Investigated host and immune factors & Association with breadth \\
\hline \multirow[t]{8}{*}{ Landais et al. [14] } & 439 & Gender & None \\
\hline & & Age & None \\
\hline & & Geographical origin & None \\
\hline & & Total plasma lgG & Positive \\
\hline & & Env-specific lgG binding titer & Positive \\
\hline & & Env-specific lgG binding avidity & None \\
\hline & & HLA genotype & Positive (HLA-A*03) \\
\hline & & KIR genotype & None \\
\hline \multirow[t]{5}{*}{ Locci et al. [79] } & 328 & $\mathrm{CXCR}^{+} \mathrm{CD}^{+}{ }^{+}$cells & None \\
\hline & & $\mathrm{ICOS}^{+} \mathrm{PD}-1^{+++} \mathrm{CXCR}^{+} \mathrm{CD}^{+} \mathrm{T}$ cells & None \\
\hline & & $\mathrm{PD}-1^{+} \mathrm{CXCR3^{- }} \mathrm{CXCR}^{+} \mathrm{CD} 4^{+}$memory Tfh cells & Positive \\
\hline & & $\mathrm{CXCR3}^{-} \mathrm{CXCR}^{+} \mathrm{CD} 4^{+} \mathrm{T}$ cells & None \\
\hline & & $\mathrm{PD}-1^{+} \mathrm{CXCR3}^{+}$memory Th cells & None \\
\hline \multirow[t]{6}{*}{ Mabuka et al. [83] } & 22 & Plasma CXCL13 & Positive \\
\hline & & Plasma BAFF & None \\
\hline & & $\mathrm{CD} 19^{+} \mathrm{CD} 21^{-} \mathrm{CD} 27^{+}$activated memory B cells & None \\
\hline & & $\mathrm{CD} 19^{+} \mathrm{CD} 21^{-} \mathrm{CD} 27^{-}$tissue-like memory B cells & None \\
\hline & & $\mathrm{CD} 19^{+} \mathrm{CD} 21^{+} \mathrm{CD} 27^{+}$resting memory B cells & None \\
\hline & & $\mathrm{CD} 19^{+} \mathrm{CD} 27^{+} \mathrm{CD} 38^{+++}$plasmablasts & None \\
\hline \multirow[t]{6}{*}{ Mikkell et al. [32] } & 38 & CD4+ and CD8 + T cell expression of: & \\
\hline & & Ki67 & None \\
\hline & & CD57 & None \\
\hline & & CD38 & Positive (CD4+ T cells) \\
\hline & & $P D-1$ & Positive (CD4+ T cells) \\
\hline & & HLADR & None \\
\hline \multirow[t]{11}{*}{ Moody et al. [75] } & 239 & HLA genotype & None \\
\hline & & Plasma autoantibodies & Positive \\
\hline & & 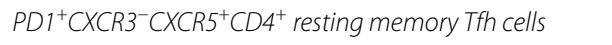 & Positive \\
\hline & & $\mathrm{CD} 25^{+} \mathrm{Foxp}^{+} \mathrm{CD}^{+}$Treg cells & Negative \\
\hline & & $\mathrm{CD}_{25}{ }^{+} \mathrm{Foxp}^{+} \mathrm{CXCR}^{+} \mathrm{CD}^{+}$follicular Treg cells & None \\
\hline & & PD- 1 expression on $\mathrm{CD} 25^{+}$Foxp $^{+} \mathrm{CD}^{+}$Treg cells & Positive \\
\hline & & $\begin{array}{l}\text { PD- } 1 \text { expression on } \mathrm{CD}_{2} 5^{+} \mathrm{Foxp}^{+} \mathrm{CXCR5}^{+} \mathrm{CD} 4^{+} \text {follicular } \\
\text { Treg cells }\end{array}$ & Positive \\
\hline & & HLA-DR expression on CD4+ Treg cells & Positive \\
\hline & & CTLA-4 expression on CD4+ Treg cells & Positive \\
\hline & & LAG-3 expression on $C D 4^{+}$Treg cells & Positive \\
\hline & & Genome-wide mutations & None \\
\hline \multirow[t]{3}{*}{ Ranasinghe et al. [77] } & 67 & Gag-specific $C D 4^{+}$responses & Positive \\
\hline & & Gp41-specific $C D 4^{+}$responses & Positive \\
\hline & & Gp120-specific $\mathrm{CD}^{+}{ }^{+}$responses & None \\
\hline
\end{tabular}


Table 2 (continued)

\begin{tabular}{|c|c|c|c|}
\hline Reference & $\begin{array}{l}\text { Number } \\
\text { of subjects }^{a}\end{array}$ & Investigated host and immune factors & Association with breadth \\
\hline \multirow[t]{13}{*}{ Richardson et al. [82] } & 23 & ADCC & None \\
\hline & & ADCP & None \\
\hline & & $A D C D$ & Positive \\
\hline & & $A D C T$ & Positive \\
\hline & & Fcpolyfunctionality & Positive \\
\hline & & FCR binding & Positive \\
\hline & & Clabinding & Positive \\
\hline & & IgG subclass diversity & Positive \\
\hline & & IgG2 binding to trimeric Env, gp 120, V3 & Positive \\
\hline & & IgG2 binding to $p 24$ & Positive \\
\hline & & IgG4 binding to trimeric Env, gp41, V2 & Positive \\
\hline & & Plasma CXCL13 & Positive \\
\hline & & AID expression in B cells & Positive \\
\hline \multirow[t]{2}{*}{ Rusert et al. [12] } & 4484 & Ethnicity & Positive (blacks compared to whites) \\
\hline & & Gender & Weakly positive (modestly higher breadth in men) \\
\hline \multirow[t]{3}{*}{ Sather et al. [49] } & 39 & Env-specific lgG binding titer & None \\
\hline & & Env-specific lgG binding avidity & Positive \\
\hline & & $\mathrm{CD}^{+} \mathrm{T}$ cell levels & None \\
\hline
\end{tabular}

${ }^{a}$ Indicates total number of subjects included. Specific analyses may have been carried out on subsets of these numbers

determinants of the virus that trigger a bnAb lineage? As discussed above, it is possible that viral diversity can foster bnAb evolution, but whether diversity at the level of the infecting virus (superinfection, multiple $\mathrm{T} / \mathrm{F}$ viruses) is decisive or not, has not been resolved.

Understanding the role of the T/F viruses may be key [9]. While no large differences in bnAb elicitation have been seen in male to male and heterosexual transmission $[11,12,14]$, bnAb activity is found more frequently after mother to child transmission $[57,58]$ (see section below) and possibly also in IDUs [12]. Whether the transmitted virus or other factors that differ in these settings underlie the elevated chances to develop bnAb responses needs to be dissected. Differential glycosylation, variable loop length and specific motifs linked with certain bnAb specificities may play a role, but could also differ dependent on subtype and transmission mode [59-64]. However, causal relationships between prospective Env features and neutralization breadth remain difficult to establish. This is also true for deciphering Env determinants that trigger germline precursors of bnAb lineages [65-69]. With few exceptions [19, 20, 22], inferred germline versions of bnAbs often lack measurable binding activity to Env probes, which are efficiently recognized by the mature bnAbs $[65-67,69-71]$. This suggests that Envs with distinct characteristics are needed for triggering these bnAbs. Intriguingly, some reports suggest that inferred germline ancestors of Abs with non/low neutralizing activity frequently bind a range of recombinant Envs with high affinity $[45,72]$. Larger numbers of bnAbs and non-neutralizing antibodies need to be investigated to confirm this disparity. However, based on their comparative ease to engage diverse Env variants, non/ low-neutralizing antibodies may have a selection advantage in the germinal center $(\mathrm{GC})$ reaction.

A main issue that has not been clarified is whether the capacity of a virus to induce a bnAb is (1) restricted to a specific Env variant that is only transiently present and lost upon Env evolution or (2) preserved over prolonged time periods and may even be stable over multiple transmissions. Despite continuous Env evolution, there is emerging proof that some Env traits are stable and evoke similar responses. Clear evidence for this stems from the comparison of bnAb specificities mounted in subtype $B$ infection compared to non-B infection. Non-B infection proved superior in mounting V2-glycan-directed responses [12], which is supported by the fact that none of the isolated potent V2 bnAbs stems from subtype $B$ infection or targets subtype B viruses efficiently [73]. In contrast, subtype B viruses were more effective in mounting CD4bs responses [12]. Thus, while the genetic subtype had no impact on the frequency of bnAb activity, it shaped the specificity of the response. Thus, specific Env features in the respective virus subtypes that direct the immune response towards a certain specificity must exist. 


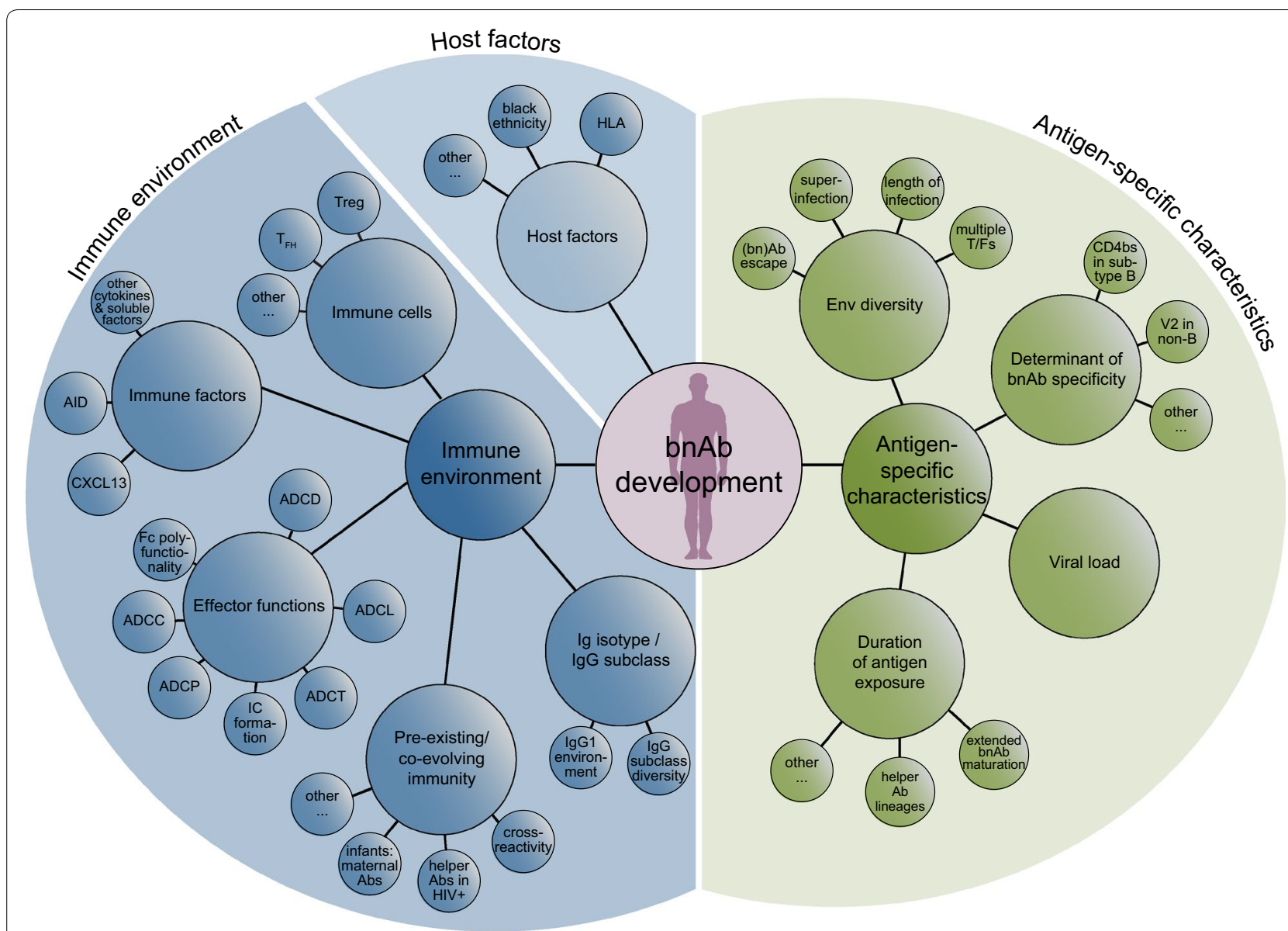

Fig. 1 Parameters implicated in bnAb development

In principle, bnAb development could be facilitated by a range of phenotypic virus features that influence epitope exposure and accessibility. These include, Env conformation and stability, the degree of shielding, and Env density on the virion surface. Unravelling genetic and/or structural Env features that promote or suppress bnAb development will be crucial for vaccine success.

\section{Immune environment}

bnAbs often show poly/autoreactivity (reviewed in [74]) and autoantibody frequency has been reported to be high in bnAb-developing individuals [75]. Autoreactivity is particularly strong in the case of MPER bnAbs 2F5 and 4E10, and immune tolerance mechanisms must be overcome for the induction of MPER bnAb responses in humanized mouse models [74]. Therfore, reduced immune control may foster bnAb development in certain cases. An indication that this may occur in natural HIV infection stems from the observation that low $\mathrm{CD} 4^{+} \mathrm{T}$ cell levels and a high rate of $\mathrm{CD} 4^{+} \mathrm{T}$ cell decline appear to be linked with broad neutralization in some cohorts $[6,14,33,50]$. While the distribution of $\mathrm{CD}^{+} \mathrm{T}$ cell subsets was not assessed directly in most studies, lower $\mathrm{CD} 4^{+} \mathrm{T}$ cell levels may implicate reduced levels of regulatory $\mathrm{CD} 4^{+} \mathrm{T}$ cells that may feed into bnAb development. However, a link between low $\mathrm{CD}^{+}{ }^{+} \mathrm{T}$ cell levels and neutralization breadth was not observed universally $[11,48,49,51]$. This may in part be due to the inverse association between $\mathrm{CD} 4^{+} \mathrm{T}$ cell counts and viral load [76]. With viral load confirmed as an independent determinant of bnAb evolution, assessing the specific effect of $\mathrm{CD}_{4}^{+} \mathrm{T}$ cell levels requires cohorts with the power to dissect confounding factors. Controlling for a range of factors, including viral load and infection length, the Swiss 4.5k Screen studying 4484 individuals found only a marginal independent impact of lower $\mathrm{CD}^{+} \mathrm{T}$ cell levels in individuals that mounted low levels of breadth and not those who had potent bnAb activity [12]. Of note, in the same cohort $\mathrm{CD} 4^{+} \mathrm{T}$ cell levels were found not to correlate with binding antibody responses to gp120, but a strong inverse effect on MPER IgG1 levels was observed [54]. 
This supports the notion that while MPER antibodies may benefit from a partially impaired immune system, the majority of bnAbs will not benefit from an environment with reduced $\mathrm{CD} 4^{+} \mathrm{T}$ cells. In fact, a recent study suggests that perturbations in the $\mathrm{CD} 4^{+} \mathrm{T}$ cell environment are linked with neutralization breadth. bnAb inducers had lower numbers of $\mathrm{PD}-1^{\text {high }}$ regulatory $\mathrm{CD}^{+} \mathrm{T}$ cells, highlighting a decreased regulatory capacity [75]. Extensive levels of SHM are commonly found in bnAbs. HIV-specific CD4 $\mathrm{T}$ cell responses have been linked with neutralization breadth [77] and elevated GC activity in bnAb inducers has been indicated by increased frequency of circulating memory $\mathrm{T}$ follicular helper $\left(\mathrm{T}_{\mathrm{FH}}\right) \mathrm{CD} 4^{+}$cells, particularly early in infection [75, 78-80]. Likewise, elevated plasma levels of CXCL13, a cytokine involved in B cell migration to the GC, and increased expression of activation-induced cytidine deaminase (AID), the enzyme that orchestrates Ig hypermutation and class switch recombination, was observed in bnAb-inducers [53, 78, 81-83].

What stimulates such beneficial immune environments has not been resolved, but host genetics are implicated by several lines of evidence. A decreased prevalence of the protective allele HLA-B*57 [84] (linked with slower disease progression) and expression of a specific HLA allele (HLA-A*03) [14] have been implicated. Likewise, other HLA variants and SNPs within the MHC complex may directly or indirectly impact bnAb evolution via influencing viral load $[11,14,75,84]$. As highlighted by CD4bs bnAbs, some bnAb specificities are restricted to a limited set of Ig heavy chain germline alleles, which encode signature features relevant for the specific epitope recognition [71]. Hence, it is possible that the ability to produce these types of antibodies is genetically restricted. However, no overall difference in the immunoglobulin gene repertoires of bnAb inducers and non-neutralizers has been observed to date [85].

In support of a strong genetic influence, individuals with black ethnicity were found to more frequently induce bnAb activity compared to white study participants [12] and have enhanced antibody binding IgG1 responses [54]. Ethnicity-dependent differences in the antibody response to a HIV-1 gp120 immunogen have independently been reported [86]. While the influence of socio-economic factors cannot be excluded, focused studies to reveal a potential genetic determinant are highly warranted. Depending on the genetic determinants identified this may or may not be relevant to vaccines. Nevertheless, their contribution needs to be determined to understand if future HIV bnAb-inducing vaccines can be expected to be effective in the whole population or only in proportions thereof.

\section{Specific antibody signatures are linked with neutralization breadth}

With increased knowledge about parameters that are linked with bnAb development in natural infection (Tables 1, 2 and Fig. 1), opportunities to define factors that promote bnAb activity and surrogate markers that predict bnAb evolution are now within reach. An important step towards this came from recent systems serology studies that investigated multiple aspects of the antibody response repertoire in vaccine recipients, non-neutralizers and individuals who developed broad neutralization activity [53, 54, 82, 87-89].

Titer [14] and avidity [49] of IgG binding responses to Env-based antigens have been reported to correlate with neutralization breadth. IgG subclass distribution of the HIV-1 antigen response shows a distinct IgG1driven pattern in bnAb inducers, suggesting the presence of immune regulatory mechanisms that promote IgG1 responses [54]. In addition, elevated IgG2 and IgG4 responses against HIV antigens in bnAb-inducers compared to non-neutralizers have been observed early in infection [82]. This may in part reflect higher antigen exposure, as IgG2 anti-Env responses are strongly driven by viral load [54]. Diverse parameters that influence the development of neutralization breadth (Tables 1,2) also impact binding antibody responses to HIV-1 but in an antigen-dependent manner [54], underscoring the complexity of these interrelations. Differential antibody profiles observed in response to HIV-1 Env vaccination regimens [87-89] suggest that modulating the immune response towards patterns that may favor bnAb evolution could be possible. However, this requires detailed knowledge of which antibody features are needed, as well as defined strategies to shift responses in the desired direction.

The importance of effector functions in the protective effect of neutralizing antibodies has been long recognized and both activity of non-neutralizing and neutralizing antibodies in the context of effector functions implicated [53, 91-96]. These include immune complex (IC) formation, antibody dependent complement deposition (ADCD) and lytic (ADCL) activity, antibody dependent cytotoxicity (ADCC), antibody dependent trogocytosis (ADCT) and antibody dependent phagocytosis (ADCP). Increased effector activity of antibodies that bind to Envexpressing infected cells with high affinity, like bnAbs, may deliver superior antiviral activity allowing elimination of infected cells-a goal of HIV-1 cure approaches [94-96].

IgG subtypes differ in their capacity to deliver effector functions and differential glycosylation of the Fc also influences the interaction with Fc receptors and the efficacy of the effector responses [97]. Considerable evidence 
suggests that steering immune responses towards certain Ig subclasses and/or Fc modifications needs to be evaluated. HIV-1 controllers display antibody subclass profiles that are skewed towards IgG1 or IgG3 responses with the ability to coordinate several effector functions including ADCC and ADCP that suppress viral replication [98100]. Similarly, immune correlates of protection in the RV144 trial have been linked to antibody effector functions [101, 102]. Systems serology approaches revealed that polyfunctional Fc-effector profiles of anti-Env responses are a critical component of viral control in natural infection $[98-100,103]$ and distinguish responses to different vaccine regimens [87-89]. When and where Fc effector activity is important, whether improved signaling capacity through immune complex formation or activation of the cell killing mechanism is required, needs to be determined. Common immune determinants that regulate both Fab and Fc mediated activities may be involved, since Fc polyfunctionality and potency early in infection have been associated with the propensity to develop neutralization breadth [82]. Increased levels of ADCD and ADCT were observed early (but not later) in infection in individuals who developed bnAbs [82]. This stresses the complexity in dissecting cause and consequence also in this context. We need to decipher to what extent Fc effector functions actively foster bnAb development and/or develop in parallel (as they depend on the same immune factors) in order to appreciate the importance of stimulating Fc effector environments by vaccination.

\section{HIV-1 infected infants develop bnAbs more frequently, more rapidly and with less SHM}

While most bnAbs have high levels of SHM and evolved after prolonged maturation pathways, this seems not to be needed in all settings. A proportion of adults develop bnAb activity comparatively rapidly [12, 20, 22, 32]. In infant HIV infection, bnAb evolution is generally fast and, with more than $70 \%$ of cases developing breadth, also substantially more frequent than in adults $[57,58]$. Deciphering the underlying causes of slow and rapid bnAb evolution in adults and infants may open new potentials for vaccine design and immunization strategies. The first infant bnAb characterized in detail highlights the potential [104]. In line with a more direct developmental pathway in infants, the N332 glycan-dependent supersite-targeting bnAb BF520.1, isolated from a HIV-1 infected infant 1 year post-infection, has notably low levels of SHM (6.6\% nt) and lacks heavy and light chain indels compared to adult V3 glycan region-targeting bnAbs [104]. If conditions that allow rapid development of low SHM bnAbs like BF520.1 prove to be transferrable to other settings this may open immense potential to create an effective bnAb vaccine in adults. Pinpointing the causative effects will however be challenging. A range of factors differ between adult and infant infection and several may feed into each other. While it seems surprising, the infant immune system appears to provide a better setting for bnAb development. In early life, B cell responses are partially restricted, the Ig germ-line repertoire is not fully developed and the co-stimulatory network is not yet fully functional, leading to compromised B cell responses with lower SHM and heterogeneity [105, 106]. IgG subclass distribution differs markedly in infants with IgG1 and IgG3 levels, the most relevant subclasses for neutralizing HIV responses [54], rising sooner to adult-like concentrations than IgG2 and IgG4 [106, 107].

While antibodies with lower SHM may prove to be common in infants, it is intriguing that bnAbs with low SHM have not been described in adults. Does the adult immune system not favor the development of low SHM bnAbs? A potential scenario could be that cross-reactive antibodies that bind to HIV Env exist in adults. Following the dogma of original antigenic sin [108], instead of priming a de novo antibody response, the evolution of the Env antibody response would be restricted to affinity maturation of a pre-existing cross-reactive antibody. This may limit the response and require more extensive SHM to reach neutralization breadth. Of note, cross-reactivity with unrelated proteins and/or host antigens have been described for several HIV bnAbs [23, 109-111].

Vertical transmission is distinct from all other HIV-1 transmissions, as maternal antibodies are transferred and remain present for prolonged time periods. The role of maternal Abs in influencing transmission risk is still debated [112-115]. Irrespective of their potential in preventing transmission, it is intriguing to speculate that maternal antibodies may function as helper antibodies $[19,40]$. The presence of maternal Abs may allow immune-focusing that aids neutralizing antibody development, as described for passive immunization of infant macaques [47]. Influence of maternal antibodies on vaccine responses in infants has been reported [107] and may comprise a number of mechanisms including activation of the immune system through IC formation that aid bnAb evolution. Specific immune-focusing of the infant response could also be envisaged through binding of immunodominant epitopes by maternal antibodies, shielding these from access by infant BCRs and thereby directing the $\mathrm{Ab}$ response to other sites without competing for survival signals in the GC reaction. In the setting of HIV-1 infection, this immediately raises the question whether neutralizing or non-neutralizing antibodies or even combinations thereof would be needed to create effective immune-focusing [116].

High viral load-a strong influence on bnAb evolution in adults-is frequent in infant HIV-1 infection in the 


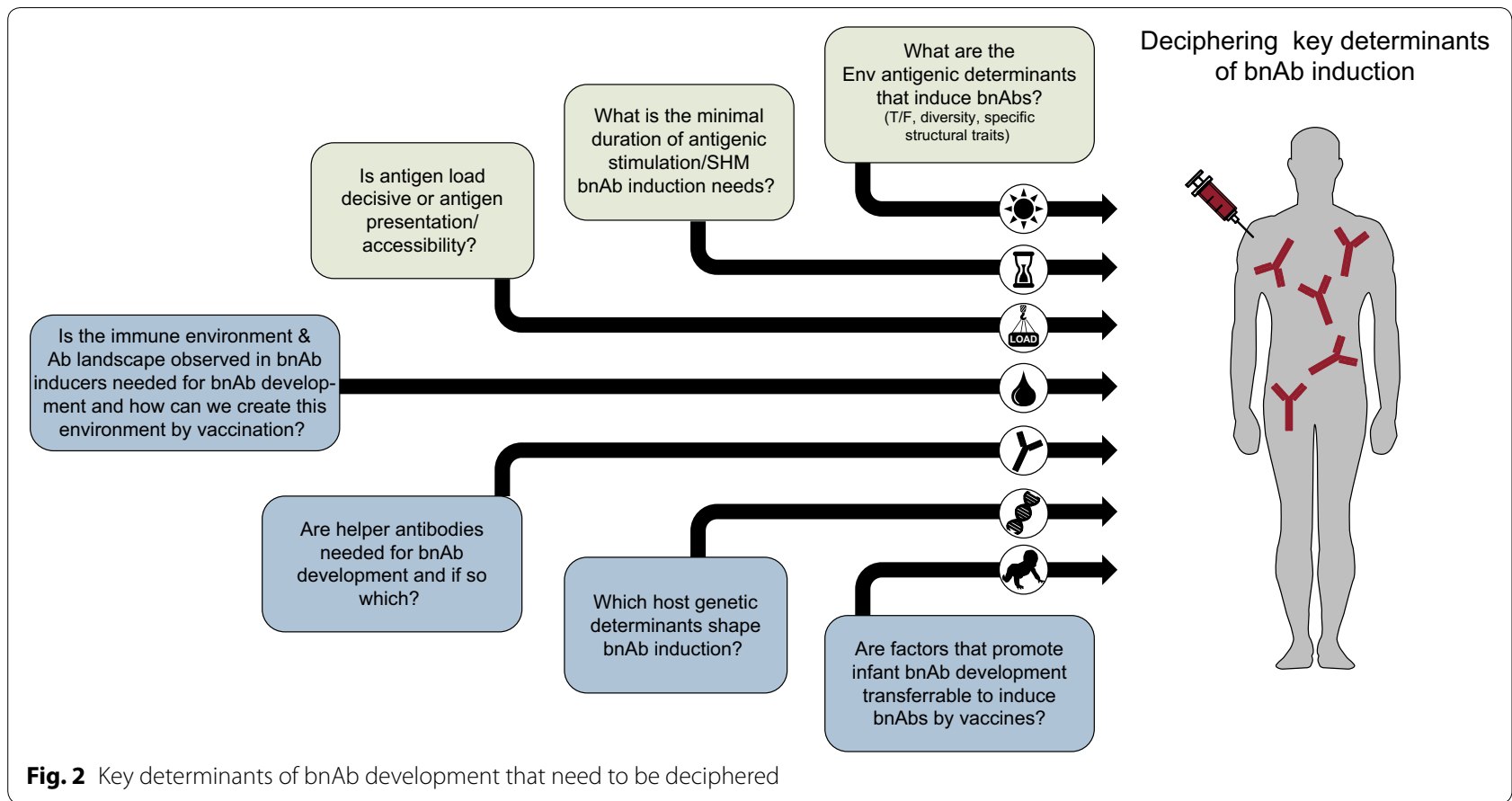

first 2 years of life $[117,118]$ and may also promote infant bnAb development as seen in adult HIV infection $[11,12$, $14,32,33,48-50]$. Importantly, vertical transmission may also create bottlenecks that differ from sexual transmission, potentially favoring transmission of phenotypically distinct strains that favor bnAb triggering. Defining the phenotypic properties of $\mathrm{T} / \mathrm{F}$ viruses from vertical transmission cases that developed Ab breadth is of high relevance. The best case scenario for vaccine design would be that specific Env properties of infant T/F viruses are the underlying cause of the frequent and rapid bnAb evolution in infant HIV infection. Of note, the T/F virus BG505, derived from an infant that developed a bnAb response [119] is the currently most thoroughly studied trimeric Env immunogen and focus of diverse immunization strategies $[119,120]$.

\section{Conclusion}

Detailed analysis of determinants that shape bnAb responses in natural infection have led to the identification of a range of factors that are linked with the development of neutralization breadth. However, so far we lack formal proof for which factors are ultimately causative in bnAb elicitation and which evolve alongside. Delineating the causes and consequences, as well as defining parameters that need to be incorporated into vaccine regimens will be critical. Figure 2 highlights key questions that need to be addressed, based on the current state of the field. Resolving these topics, ranging from the impact of the Env immunogen and the immune environment in which the bnAb response favorably evolves, to understanding why the infant HIV-1 infection is superior in mounting bnAb responses, will be challenging. However, this is ultimately necessary to move HIV vaccine design forward.

Authors' contributions

HS, MS and AT wrote this article together and give their consent to publication. All authors read and approved the final manuscript.

Acknowledgements

We thank Claus Kadelka and Melissa Robbiani for critical reading.

\section{Competing interests}

The authors declare that they have no competing interests.

Availability of data and materials Not applicable.

Consent for publication

Not applicable.

Ethics approval and consent to participate Not applicable.

Funding

Financial support has been provided by the Swiss National Science Foundation (SNF \#314730_172790 to AT).

\section{Publisher's Note}

Springer Nature remains neutral with regard to jurisdictional claims in published maps and institutional affiliations. 
Received: 18 May 2018 Accepted: 21 July 2018

Published online: 28 July 2018

\section{References}

1. Burton DR, Hangartner L. Broadly neutralizing antibodies to HIV and their role in vaccine design. Annu Rev Immunol. 2016;34:635-59.

2. Nishimura Y, Martin MA. Of mice, macaques, and men: broadly neutralizing antibody immunotherapy for HIV-1. Cell Host Microbe. 2017:22(2):207-16.

3. Bhiman JN, Anthony C, Doria-Rose NA, Karimanzira O, Schramm CA, Khoza T, Kitchin D, Botha G, Gorman J, Garrett NJ, et al. Viral variants that initiate and drive maturation of V1V2-directed HIV-1 broadly neutralizing antibodies. Nat Med. 2015;21(11):1332-6.

4. Bonsignori M, Liao HX, Gao F, Williams WB, Alam SM, Montefiori DC, Haynes BF. Antibody-virus co-evolution in HIV infection: paths for HIV vaccine development. Immunol Rev. 2017;275(1):145-60.

5. Wibmer CK, Bhiman JN, Gray ES, Tumba N, Abdool Karim SS, Williamson C, Morris L, Moore PL. Viral escape from HIV-1 neutralizing antibodies drives increased plasma neutralization breadth through sequential recognition of multiple epitopes and immunotypes. PLoS Pathog. 2013;9(10):e1003738.

6. Euler Z, van Gils MJ, Bunnik EM, Phung P, Schweighardt B, Wrin T, Schuitemaker $\mathrm{H}$. Cross-reactive neutralizing humoral immunity does not protect from HIV type 1 disease progression. J Infect Dis. 2010;201(7):1045-53.

7. Ferrari G, Pollara J, Tomaras GD, Haynes BF. Humoral and innate antiviral immunity as tools to clear persistent HIV infection. J Infect Dis. 2017;215(suppl_3):S152-9.

8. Pegu A, Hessell AJ, Mascola JR, Haigwood NL. Use of broadly neutralizing antibodies for HIV-1 prevention. Immunol Rev. 2017;275(1):296-312.

9. Joseph SB, Swanstrom R, Kashuba AD, Cohen MS. Bottlenecks in HIV-1 transmission: insights from the study of founder viruses. Nat Rev Microbiol. 2015;13(7):414-25.

10. Hraber P, Seaman MS, Bailer RT, Mascola JR, Montefiori DC, Korber BT. Prevalence of broadly neutralizing antibody responses during chronic HIV-1 infection. Aids. 2014;28(2):163-9.

11. Doria-Rose NA, Klein RM, Daniels MG, O'Dell S, Nason M, Lapedes A, Bhattacharya T, Migueles SA, Wyatt RT, Korber BT, et al. Breadth of human immunodeficiency virus-specific neutralizing activity in sera: clustering analysis and association with clinical variables. J Virol. 2010;84(3):1631-6.

12. Rusert P, Kouyos RD, Kadelka C, Ebner H, Schanz M, Huber M, Braun DL, Hoze N, Scherrer A, Magnus C, et al. Determinants of HIV-1 broadly neutralizing antibody induction. Nat Med. 2016;22(11):1260-7.

13. Simek MD, Rida W, Priddy FH, Pung P, Carrow E, Laufer DS, Lehrman $J K$, Boaz M, Tarragona-Fiol T, Miiro G, et al. Human immunodeficiency virus type 1 elite neutralizers: individuals with broad and potent neutralizing activity identified by using a high-throughput neutralization assay together with an analytical selection algorithm. J Virol. 2009:83(14):7337-48.

14. Landais E, Huang $X$, Havenar-Daughton C, Murrell B, Price MA, Wickramasinghe L, Ramos A, Bian CB, Simek M, Allen S, et al. Broadly neutralizing antibody responses in a large longitudinal sub-Saharan HIV primary infection cohort. PLoS Pathog. 2016;12(1):e1005369.

15. Sanders RW, Moore JP. Native-like Env trimers as a platform for HIV-1 vaccine design. Immunol Rev. 2017;275(1):161-82.

16. Pancera M, Changela A, Kwong PD. How HIV-1 entry mechanism and broadly neutralizing antibodies guide structure-based vaccine design Curr Opin HIV AIDS. 2017;12(3):229-40.

17. MacLeod DT, Choi NM, Briney B, Garces F, Ver LS, Landais E, Murrell B, Wrin T, Kilembe W, Liang CH, et al. Early antibody lineage diversification and independent limb maturation lead to broad HIV-1 neutralization targeting the env high-mannose Patch. Immunity. 2016;44(5):1215-26.

18. Gao F, Bonsignori M, Liao HX, Kumar A, Xia SM, Lu X, Cai F, Hwang KK, Song $\mathrm{H}$, Zhou T, et al. Cooperation of $\mathrm{B}$ cell lineages in induction of HIV1-broadly neutralizing antibodies. Cell. 2014;158(3):481-91.

19. Bonsignori M, Zhou T, Sheng Z, Chen L, Gao F, Joyce MG, Ozorowski G, Chuang GY, Schramm CA, Wiehe K, et al. Maturation pathway from germline to broad HIV-1 neutralizer of a CD4-mimic antibody. Cell. 2016;165(2):449-63.

20. Doria-Rose NA, Schramm CA, Gorman J, Moore PL, Bhiman JN, DeKosky BJ, Ernandes MJ, Georgiev IS, Kim HJ, Pancera M, et al. Developmental pathway for potent V1V2-directed HIV-neutralizing antibodies. Nature. 2014;509(7498):55-62.

21. Wu XL, Zhou TQ, Zhu J, Zhang BS, Georgiev I, Wang C, Chen XJ, Longo NS, Louder M, McKee K, et al. Focused evolution of HIV-1 neutralizing antibodies revealed by structures and deep sequencing. Science. 2011;333(6049):1593-602.

22. Liao HX, Lynch R, Zhou T, Gao F, Alam SM, Boyd SD, Fire AZ, Roskin KM, Schramm CA, Zhang Z, et al. Co-evolution of a broadly neutralizing HIV-1 antibody and founder virus. Nature. 2013:496(7446):469-76.

23. Bonsignori M, Hwang KK, Chen X, Tsao CY, Morris L, Gray E, Marshall DJ, Crump JA, Kapiga SH, Sam NE, et al. Analysis of a clonal lineage of HIV-1 envelope V2N3 conformational epitope-specific broadly neutralizing antibodies and their inferred unmutated common ancestors. J Virol. 2011:85(19):9998-10009.

24. Moore PL, Gray ES, Wibmer CK, Bhiman JN, Nonyane M, Sheward DJ, Hermanus T, Bajimaya S, Tumba NL, Abrahams MR, et al. Evolution of an HIV glycan-dependent broadly neutralizing antibody epitope through immune escape. Nat Med. 2012;18(11):1688-92.

25. Williams KL, Wang B, Arenz D, Williams JA, Dingens AS, Cortez V, Simonich CA, Rainwater S, Lehman DA, Lee KK, et al. Superinfection drives HIV neutralizing antibody responses from several B cell lineages that contribute to a polyclonal repertoire. Cell Rep. 2018;23(3):682-91.

26. Powell RL, Kinge T, Nyambi PN. Infection by discordant strains of HIV-1 markedly enhances the neutralizing antibody response against heterologous virus. J Virol. 2010;84(18):9415-26.

27. Cortez V, Odem-Davis K, McClelland RS, Jaoko W, Overbaugh J. HIV-1 superinfection in women broadens and strengthens the neutralizing antibody response. PLoS Pathog. 2012;8(3):e1002611.

28. Moore PL, Sheward D, Nonyane M, Ranchobe N, Hermanus T, Gray ES, Abdool Karim SS, Williamson C, Morris L. Multiple pathways of escape from HIV broadly cross-neutralizing V2-dependent antibodies. J Virol. 2013;87(9):4882-94.

29. van Gils MJ, Bunnik EM, Burger JA, Jacob Y, Schweighardt B, Wrin T, Schuitemaker $\mathrm{H}$. Rapid escape from preserved cross-reactive neutralizing humoral immunity without loss of viral fitness in HIV-1-infected progressors and long-term nonprogressors. J Virol. 2010;84(7):3576-85.

30. Wu X, Wang C, O'Dell S, Li Y, Keele BF, Yang Z, Imamichi H, Doria-Rose $\mathrm{N}$, Hoxie JA, Connors $\mathrm{M}$, et al. Selection pressure on HIV-1 envelope by broadly neutralizing antibodies to the conserved CD4-binding site. J Virol. 2012;86(10):5844-56.

31. Sather DN, Carbonetti S, Kehayia J, Kraft Z, Mikell I, Scheid JF, Klein F, Stamatatos L. Broadly neutralizing antibodies developed by an HIV-positive elite neutralizer exact a replication fitness cost on the contemporaneous virus. J Virol. 2012;86(23):12676-85.

32. Mikell I, Sather DN, Kalams SA, Altfeld M, Alter G, Stamatatos L. Characteristics of the earliest cross-neutralizing antibody response to HIV-1. PLoS Pathog. 2011;7(1):e1001251.

33. Gray ES, Madiga MC, Hermanus T, Moore PL, Wibmer CK, Tumba NL, Werner L, Mlisana K, Sibeko S, Williamson C, et al. The neutralization breadth of HIV-1 develops incrementally over four years and is associated with CD4+ T cell decline and high viral load during acute infection. JVirol. 2011;85(10):4828-40.

34. Euler Z, van den Kerkhof TL, van Gils MJ, Burger JA, Edo-Matas D, Phung P, Wrin T, Schuitemaker H. Longitudinal analysis of early HIV-1-specific neutralizing activity in an elite neutralizer and in five patients who developed cross-reactive neutralizing activity. J Virol. 2012;86(4):2045-55.

35. Landais E, Murrell B, Briney B, Murrell S, Rantalainen K, Berndsen ZT, Ramos A, Wickramasinghe L, Smith ML, Eren K, et al. HIV envelope glycoform heterogeneity and localized diversity govern the initiation and maturation of a V2 apex broadly neutralizing antibody lineage. Immunity. 2017:47(5):990-1003.e1009.

36. Doria-Rose NA, Bhiman JN, Roark RS, Schramm CA, Gorman J, Chuang GY, Pancera M, Cale EM, Ernandes MJ, Louder MK, et al. New member of the V1V2-Directed CAP256-VRC26 lineage that shows increased breadth and exceptional potency. J Virol. 2015;90(1):76-91. 
37. Klein F, Diskin R, Scheid JF, Gaebler C, Mouquet H, Georgiev IS, Pancera M, Zhou T, Incesu RB, Fu BZ, et al. Somatic mutations of the immunoglobulin framework are generally required for broad and potent HIV-1 neutralization. Cell. 2013;153(1):126-38.

38. Reh L, Magnus C, Kadelka C, Kuhnert D, Uhr T, Weber J, Morris L, Moore PL, Trkola A. Phenotypic deficits in the HIV-1 envelope are associated with the maturation of a V2-directed broadly neutralizing antibody lineage. PLoS Pathog. 2018;14(1):e1006825.

39. Freund NT, Wang $H$, Scharf L, Nogueira L, Horwitz JA, Bar-On Y, Golijanin J, Sievers SA, Sok D, Cai H, et al. Coexistence of potent HIV-1 broadly neutralizing antibodies and antibody-sensitive viruses in a viremic controller. Sci Transl Med. 2017;9(373):eaal2144.

40. Anthony C, York T, Bekker V, Matten D, Selhorst P, Ferreria RC, Garrett NJ, Karim SSA, Morris L, Wood NT, et al. Cooperation between strainspecific and broadly neutralizing responses limited viral escape and prolonged the exposure of the broadly neutralizing epitope. J Virol. 2017;91(18):e00828-17.

41. Abela IA, Berlinger L, Schanz M, Reynell L, Gunthard HF, Rusert P, Trkola A. Cell-cell transmission enables HIV-1 to evade inhibition by potent CD4bs directed antibodies. PLoS Pathog. 2012;8(4):e1002634.

42. Malbec M, Porrot F, Rua R, Horwitz J, Klein F, Halper-Stromberg A, Scheid JF, Eden C, Mouquet H, Nussenzweig MC, et al. Broadly neutralizing antibodies that inhibit HIV-1 cell to cell transmission. J Exp Med. 2013;210(13):2813-21.

43. Li H, Zony C, Chen P, Chen BK. Reduced potency and incomplete neutralization of broadly neutralizing antibodies against cell-tocell transmission of HIV-1 with transmitted founder Envs. J Virol. 2017;91(9):e02425-16

44. Luo SS, Perelson AS. Competitive exclusion by autologous antibodies can prevent broad HIV-1 antibodies from arising. Proc Natl Acad Sci USA. 2015:112(37):11654-9.

45. McGuire AT, Dreyer AM, Carbonetti S, Lippy A, Glenn J, Scheid JF, Mouquet $\mathrm{H}$, Stamatatos L. HIV antibodies. Antigen modification regulates competition of broad and narrow neutralizing HIV antibodies. Science. 2014;346(6215):1380-3.

46. Schoofs T, Klein F, Braunschweig M, Kreider EF, Feldmann A, Nogueira L, Oliveira T, Lorenzi JC, Parrish EH, Learn GH, et al. HIV-1 therapy with monoclonal antibody 3BNC117 elicits host immune responses against HIV-1. Science. 2016;352(6288):997-1001.

47. $\mathrm{Ng} \mathrm{CT}$, Jaworski JP, Jayaraman P, Sutton WF, Delio P, Kuller L, Anderson D, Landucci G, Richardson BA, Burton DR, et al. Passive neutralizing antibody controls SHIV viremia and enhances B cell responses in infant macaques. Nat Med. 2010;16(10):1117-9.

48. Piantadosi A, Panteleeff D, Blish CA, Baeten JM, Jaoko W, McClelland RS, Overbaugh J. Breadth of neutralizing antibody response to human immunodeficiency virus type 1 is affected by factors early in infection but does not influence disease progression. J Virol. 2009;83(19):10269-74.

49. Sather DN, Armann J, Ching LK, Mavrantoni A, Sellhorn G, Caldwell Z, Yu X, Wood B, Self S, Kalams S, et al. Factors associated with the development of cross-reactive neutralizing antibodies during human immunodeficiency virus type 1 infection. J Virol. 2009;83(2):757-69.

50. van Gils MJ, Euler Z, Schweighardt B, Wrin T, Schuitemaker H. Prevalence of cross-reactive HIV-1-neutralizing activity in HIV-1-infected patients with rapid or slow disease progression. Aids. 2009:23(18):2405-14.

51. Doria-Rose NA, Klein RM, Manion MM, O'Dell S, Phogat A, Chakrabarti B, Hallahan CW, Migueles SA, Wrammert J, Ahmed R, et al. Frequency and phenotype of human immunodeficiency virus envelope-specific B cells from patients with broadly cross-neutralizing antibodies. J Virol. 2009:83(1):188-99.

52. Scheid JF, Mouquet $H$, Feldhahn N, Seaman MS, Velinzon K, Pietzsch J, Ott RG, Anthony RM, Zebroski H, Hurley A, et al. Broad diversity of neutralizing antibodies isolated from memory B cells in HIV-infected individuals. Nature. 2009;458(7238):636-40.

53. Dugast A-S, Arnold K, Lofano G, Moore S, Hoffner M, Simek M, Poignard $P$, Seaman M, Suscovich TJ, Pereyra F, et al. Virus-driven inflammation is associated with the development of bNAbs in spontaneous controllers of HIV. Clin Infect Dis. 2017;64(8):1098-104.

54. Kadelka C, Liechti T, Ebner H, Schanz M, Rusert P, Friedrich N, Stiegeler E, Braun DL, Huber M, Scherrer AU, et al. Distinct, IgG1 driven antibody response landscapes demarcate individuals with broadly HIV-1 neutralizing activity. J Exp Med. 2018;215(6):1589-608.

55. Ronen K, Dingens AS, Graham SM, Jaoko W, Mandaliya K, McClelland RS, Overbaugh J. Comprehensive characterization of humoral correlates of human immunodeficiency virus 1 superinfection acquisition in highrisk Kenyan women. EBioMedicine. 2017;18:216-24.

56. Courtney CR, Mayr L, Nanfack AJ, Banin AN, Tuen M, Pan R, Jiang $X$, Kong X-P, Kirkpatrick AR, Bruno D, et al. Contrasting antibody responses to intrasubtype superinfection with CRF02_AG. PLOS ONE. 2017;12(3):e0173705

57. Goo L, Chohan V, Nduati R, Overbaugh J. Early development of broadly neutralizing antibodies in HIV-1-infected infants. Nat Med. 2014;20(6):655-8

58. Muenchhoff M, Adland E, Karimanzira O, Crowther C, Pace M, Csala A, Leitman E, Moonsamy A, McGregor C, Hurst J, et al. Nonprogressing HIV-infected children share fundamental immunological features of nonpathogenic SIV infection. Sci Transl Med. 2016;8(358):358ra125.

59. Smith SA, Burton SL, Kilembe W, Lakhi S, Karita E, Price M, Allen S, Hunter E, Derdeyn CA. Diversification in the HIV-1 envelope hypervariable domains V2, V4, and V5 and higher probability of transmitted/ founder envelope glycosylation favor the development of heterologous neutralization breadth. PLoS Pathog. 2016;12(11):e1005989.

60. Rademeyer C, Korber B, Seaman MS, Giorgi EE, Thebus R, Robles A, Sheward DJ, Wagh K, Garrity J, Carey BR, et al. Features of recently transmitted HIV-1 clade $C$ viruses that impact antibody recognition: implications for active and passive immunization. PLOS Pathog. 2016;12(7):e1005742

61. van den Kerkhof TLGM, Feenstra KA, Euler Z, van Gils MJ, Rijsdijk LWE, Boeser-Nunnink BD, Heringa J, Schuitemaker H, Sanders RW. HIV-1 envelope glycoprotein signatures that correlate with the development of cross-reactive neutralizing activity. Retrovirology. 2013;10(1):102.

62. Gnanakaran S, Daniels MG, Bhattacharya T, Lapedes AS, Sethi A, Li M, Tang H, Greene K, Gao H, Haynes BF, et al. Genetic signatures in the envelope glycoproteins of HIV-1 that associate with broadly neutralizing antibodies. PLoS Comput Biol. 2010;6(10):e1000955.

63. Li M, Salazar-Gonzalez JF, Derdeyn CA, Morris L, Williamson C, Robinson JE, Decker JM, Li Y, Salazar MG, Polonis VR, et al. Genetic and neutralization properties of subtype $\mathrm{C}$ human immunodeficiency virus type 1 molecular env clones from acute and early heterosexually acquired infections in southern Africa. JVirol. 2006;80(23):11776-90.

64. Hraber P, Korber BT, Lapedes AS, Bailer RT, Seaman MS, Gao H, Greene KM, McCutchan F, Williamson C, Kim JH, et al. Impact of clade, geography, and age of the epidemic on HIV-1 neutralization by antibodies. J Virol. 2014;88(21):12623-43.

65. Xiao X, Chen W, Feng Y, Zhu Z, Prabakaran P, Wang Y, Zhang MY, Longo NS, Dimitrov DS. Germline-like predecessors of broadly neutralizing antibodies lack measurable binding to HIV-1 envelope glycoproteins: implications for evasion of immune responses and design of vaccine immunogens. Biochem Biophys Res Commun. 2009;390(3):404-9.

66. Hoot S, McGuire AT, Cohen KW, Strong RK, Hangartner L, Klein F, Diskin R, Scheid JF, Sather DN, Burton DR, et al. Recombinant HIV envelope proteins fail to engage germline versions of anti-CD4bs bNAbs. PLoS Pathog. 2013;9(1):e1003106.

67. McGuire AT, Hoot S, Dreyer AM, Lippy A, Stuart A, Cohen KW, Jardine J, Menis S, Scheid JF, West AP, et al. Engineering HIV envelope protein to activate germline $B$ cell receptors of broadly neutralizing anti-CD4 binding site antibodies. J Exp Med. 2013;210:655-63.

68. Zhou T, Zhu J, Wu X, Moquin S, Zhang B, Acharya P, Georgiev IS, Altae-Tran HR, Chuang GY, Joyce MG, et al. Multidonor analysis reveals structural elements, genetic determinants, and maturation pathway for HIV-1 neutralization by VRC01-class antibodies. Immunity. 2013:39(2):245-58.

69. Jardine J, Julien JP, Menis S, Ota T, Kalyuzhniy O, McGuire A, Sok D, Huang PS, MacPherson S, Jones M, et al. Rational HIV immunogen design to target specific germline B cell receptors. Science. 2013;340(6133):711-6.

70. Scheid JF, Mouquet H, Ueberheide B, Diskin R, Klein F, Oliveira TY, Pietzsch J, Fenyo D, Abadir A, Velinzon K, et al. Sequence and structural convergence of broad and potent HIV antibodies that mimic CD4 binding. Science. 2011;333(6049):1633-7. 
71. Zhou T, Lynch RM, Chen L, Acharya P, Wu X, Doria-Rose NA, Joyce MG, Lingwood D, Soto C, Bailer RT, et al. Structural repertoire of HIV1-neutralizing antibodies targeting the CD4 supersite in 14 donors. Cell. 2015;161(6):1280-92.

72. Mouquet H, Scheid JF, Zoller MJ, Krogsgaard M, Ott RG, Shukair S, Artyomov MN, Pietzsch J, Connors M, Pereyra F, et al. Polyreactivity increases the apparent affinity of anti-HIV antibodies by heteroligation. Nature. 2010;467(7315):591-5.

73. Yoon H, Macke J, West AP Jr, Foley B, Bjorkman PJ, Korber B, Yusim K. CATNAP: a tool to compile, analyze and tally neutralizing antibody panels. Nucl Acids Res. 2015;43(W1):W213-9.

74. Kelsoe G, Haynes BF. Host controls of HIV broadly neutralizing antibody development. Immunol Rev. 2017:275(1):79-88.

75. Moody MA, Pedroza-Pacheco I, Vandergrift NA, Chui C, Lloyd KE, Parks R, Soderberg KA, Ogbe AT, Cohen MS, Liao HX, et al. Immune perturbations in HIV-1-infected individuals who make broadly neutralizing antibodies. Sci Immunol. 2016;1 (1):aag0851.

76. Mellors JW, Munoz A, Giorgi JV, Margolick JB, Tassoni CJ, Gupta P, Kingsley LA, Todd JA, Saah AJ, Detels R, et al. Plasma viral load and CD4+ lymphocytes as prognostic markers of HIV-1 infection. Ann Intern Med. 1997;126(12):946-54.

77. Ranasinghe S, Soghoian DZ, Lindqvist M, Ghebremichael M, Donaghey F, Carrington M, Seaman MS, Kaufmann DE, Walker BD, Porichis F. HIV-1 antibody neutralization breadth is associated with enhanced HIVspecific CD4+ T cell responses. J Virol. 2015;90(5):2208-20.

78. Cohen K, Altfeld M, Alter G, Stamatatos L. Early preservation of CXCR5+ $\mathrm{PD}-1+$ helper $\mathrm{T}$ cells and $\mathrm{B}$ cell activation predict the breadth of neutralizing antibody responses in chronic HIV-1 infection. J Virol. 2014;88(22):13310-21.

79. Locci M, Havenar-Daughton C, Landais E, Wu J, Kroenke MA, Arlehamn CL, Su LF, Cubas R, Davis MM, Sette A, et al. Human circulating PD-1+CXCR3-CXCR5+ memory Tfh cells are highly functional and correlate with broadly neutralizing HIV antibody responses. Immunity. 2013;39(4):758-69.

80. Yamamoto T, Lynch RM, Gautam R, Matus-Nicodemos R, Schmidt SD, Boswell KL, Darko S, Wong P, Sheng Z, Petrovas C, et al. Quality and quantity of TFH cells are critical for broad antibody development in SHIVAD8 infection. Sci Transl Med. 2015:7(298):298ra120.

81. Havenar-Daughton C, Lindqvist M, Heit A, Wu JE, Reiss SM, Kendric K, Bélanger S, Kasturi SP, Landais E, Akondy RS, et al. CXCL13 is a plasma biomarker of germinal center activity. Proc Natl Acad Sci. 2016;113(10):2702.

82. Richardson SI, Chung AW, Natarajan H, Mabvakure B, Mkhize NN, Garrett N, Abdool Karim S, Moore PL, Ackerman ME, Alter G, et al. HIV-specific Fc effector function early in infection predicts the development of broadly neutralizing antibodies. PLoS Pathog. 2018;14(4):e1006987.

83. Mabuka JM, Dugast AS, Muema DM, Reddy T, Ramlakhan Y, Euler Z, Ismail N, Moodley A, Dong KL, Morris L, et al. Plasma CXCL13 but Not $B$ cell frequencies in acute HIV infection predicts emergence of crossneutralizing antibodies. Front Immunol. 2017;8:1104.

84. Euler Z, van Gils MJ, Boeser-Nunnink BD, Schuitemaker $H$, van Manen D. Genome-wide association study on the development of crossreactive neutralizing antibodies in HIV-1 infected individuals. PLoS ONE. 2013;8(1):e54684.

85. Scheepers C, Shrestha RK, Lambson BE, Jackson KJ, Wright IA, Naicker D, Goosen M, Berrie L, Ismail A, Garrett N, et al. Ability to develop broadly neutralizing HIV-1 antibodies is not restricted by the germline Ig gene repertoire. J Immunol. 2015;194(9):4371-8.

86. Montefiori DC, Metch B, McElrath MJ, Self S, Weinhold KJ, Corey L. Network HIVVT: demographic factors that influence the neutralizing antibody response in recipients of recombinant HIV-1 gp120 vaccines. $J$ Infect Dis. 2004;190(11):1962-9.

87. Chung AW, Kumar MP, Arnold KB, Yu WH, Schoen MK, Dunphy L, Suscovich TJ, Frahm N, Linde C, Mahan AE, et al. Dissecting polyclonal vaccine-induced humoral immunity against HIV using systems serology. Cell. 2015;163(4):988-98.

88. Chung AW, Ghebremichael M, Robinson H, Brown E, Choi I, Lane S, Dugast A-S, Schoen MK, Rolland M, Suscovich TJ, et al. Polyfunctional Fc-effector profiles mediated by lgG subclass selection distinguish RV144 and VAX003 vaccines. Sci Transl Med. 2014;6(228):228ra238.
89. Mahan AE, Jennewein MF, Suscovich T, Dionne K, Tedesco J, Chung AW, Streeck H, Pau M, Schuitemaker H, Francis D, et al. Antigen-specific antibody glycosylation is regulated via vaccination. PLoS Pathog. 2016;12(3):e1005456.

90. Boliar S, Murphy MK, Tran TC, Carnathan DG, Armstrong WS, Silvestri G, Derdeyn CA. B-lymphocyte dysfunction in chronic HIV-1 infection does not prevent cross-clade neutralization breadth. J Virol. 2012;86(15):8031-40.

91. Bournazos S, Klein F, Pietzsch J, Seaman MS, Nussenzweig MC, Ravetch $J V$. Broadly neutralizing anti-HIV-1 antibodies require Fc effector functions for in vivo activity. Cell. 2014;158(6):1243-53.

92. Hessell AJ, Hangartner L, Hunter M, Havenith CEG, Beurskens FJ, Bakker JM, Lanigan CMS, Landucci G, Forthal DN, Parren PWHI, et al. Fc receptor but not complement binding is important in antibody protection against HIV. Nature. 2007;449:101.

93. Huber M, Trkola A. Humoral immunity to HIV-1: neutralization and beyond. J Intern Med. 2007;262(1):5-25.

94. Halper-Stromberg A, Lu CL, Klein F, Horwitz JA, Bournazos S, Nogueira L, Eisenreich TR, Liu C, Gazumyan A, Schaefer U, et al. Broadly neutralizing antibodies and viral inducers decrease rebound from HIV-1 latent reservoirs in humanized mice. Cell. 2014;158(5):989-99.

95. Lu CL, Murakowski DK, Bournazos S, Schoofs T, Sarkar D, Halper-Stromberg A, Horwitz JA, Nogueira L, Golijanin J, Gazumyan A, et al. Enhanced clearance of HIV-1-infected cells by broadly neutralizing antibodies against HIV-1 in vivo. Science. 2016;352(6288):1001-4.

96. Bruel T, Guivel-Benhassine F, Amraoui S, Malbec M, Richard L, Bourdic K, Donahue DA, Lorin V, Casartelli N, Noël N, et al. Elimination of HIV-1-infected cells by broadly neutralizing antibodies. Nat Commun. 2016;7:10844

97. Lu LL, Suscovich TJ, Fortune SM, Alter G. Beyond binding: antibody effector functions in infectious diseases. Nat Rev Immunol. 2018;18(1):46-61

98. Ackerman ME, Mikhailova A, Brown EP, Dowell KG, Walker BD, BaileyKellogg C, Suscovich TJ, Alter G. Polyfunctional HIV-specific antibody responses are associated with spontaneous HIV control. PLoS Pathog. 2016;12(1):e1005315.

99. Lai Jl, Licht AF, Dugast AS, Suscovich T, Choi I, Bailey-Kellogg C, Alter G, Ackerman ME. Divergent antibody subclass and specificity profiles but not protective HLA-B alleles are associated with variable antibody effector function among HIV-1 controllers. J Virol. 2014;88(5):2799-809.

100. Sadanand S, Das J, Chung AW, Schoen MK, Lane S, Suscovich TJ, Streeck H, Smith DM, Little SJ, Lauffenburger DA, et al. Temporal variation in HIV-specific lgG subclass antibodies during acute infection differentiates spontaneous controllers from chronic progressors. Aids. 2018;32(4):443-50.

101. Haynes BF, Gilbert PB, McElrath MJ, Zolla-Pazner S, Tomaras GD, Alam SM, Evans DT, Montefiori DC, Karnasuta C, Sutthent R, et al. Immunecorrelates analysis of an $\mathrm{HIV}-1$ vaccine efficacy trial. N Engl J Med. 2012;366(14):1275-86.

102. Tomaras GD, Ferrari G, Shen X, Alam SM, Liao HX, Pollara J, Bonsignori M Moody MA, Fong $Y$, Chen $X$, et al. Vaccine-induced plasma IgA specific for the $\mathrm{C} 1$ region of the HIV-1 envelope blocks binding and effector function of lgG. Proc Natl Acad Sci USA. 2013;110(22):9019-24.

103. Ackerman ME, Crispin M, Yu X, Baruah K, Boesch AW, Harvey DJ, Dugast AS, Heizen EL, Ercan A, Choi l, et al. Natural variation in Fc glycosylation of HIV-specific antibodies impacts antiviral activity. J Clin Invest. 2013;123(5):2183-92.

104. Simonich CA, Williams KL, Verkerke HP, Williams JA, Nduati R, Lee KK, Overbaugh J. HIV-1 neutralizing antibodies with limited hypermutation from an infant. Cell. 2016;166(1):77-87.

105. Simon AK, Hollander GA, McMichael A. Evolution of the immune system in humans from infancy to old age. Proc Biol Sci. 1821;2015(282):20143085.

106. Tobin NH, Aldrovandi GM. Immunology of pediatric HIV infection. Immunol Rev. 2013;254(1):143-69.

107. Siegrist CA, Aspinall R. B-cell responses to vaccination at the extremes of age. Nat Rev Immunol. 2009;9(3):185-94.

108. Francis T. On the doctrine of original antigenic sin. Proc Am Philos Soc. 1960;104(6):572-8.

109. Liao HX, Chen X, Munshaw S, Zhang R, Marshall DJ, Vandergrift N, Whitesides JF, Lu X, Yu JS, Hwang KK, et al. Initial antibodies binding 
to HIV-1 gp41 in acutely infected subjects are polyreactive and highly mutated. J Exp Med. 2011;208(11):2237-49.

110. Liu MF, Yang G, Wiehe K, Nicely NI, Vandergrift NA, Rountree W, Bonsignori M, Alam SM, Gao JY, Haynes BF, et al. Polyreactivity and autoreactivity among HIV-1 antibodies. J Virol. 2015;89(1):784-98.

111. Mouquet H, Scharf L, Euler Z, Liu Y, Eden C, Scheid JF, Halper-Stromberg A, Gnanapragasam PN, Spencer DI, Seaman MS, et al. Complex-type $\mathrm{N}$-glycan recognition by potent broadly neutralizing HIV antibodies. Proc Natl Acad Sci USA. 2012;109(47):E3268-77.

112. Ghulam-Smith M, Olson A, White LF, Chasela CS, Ellington SR, Kourtis AP, Jamieson DJ, Tegha G, van der Horst CM, Sagar M. Maternal but not infant anti-HIV-1 neutralizing antibody response associates with enhanced transmission and infant morbidity. mBio. 2017;8(5):e01373-17.

113. Omenda MM, Milligan C, Odem-Davis K, Nduati R, Richardson BA, Lynch J, John-Stewart G, Overbaugh J. Evidence for efficient vertical transfer of maternal HIV-1 envelope-specific neutralizing antibodies but no association of such antibodies with reduced infant infection. J Acquir Immune Defic Syndr. 2013;64(2):163-6.

114. Lynch JB, Nduati R, Blish CA, Richardson BA, Mabuka JM, Jalalian-Lechak Z, John-Stewart G, Overbaugh J. The breadth and potency of passively acquired human immunodeficiency virus type 1-specific neutralizing antibodies do not correlate with the risk of infant infection. J Virol. 2011;85(11):5252-61.
115. Overbaugh J. Mother-infant HIV transmission: do maternal HIV-specific antibodies protect the infant? PLoS Pathog. 2014;10(8):e1004283.

116. Horwitz JA, Bar-On Y, Lu CL, Fera D, Lockhart AAK, Lorenzi JCC, Nogueira L, Golijanin J, Scheid JF, Seaman MS, et al. Non-neutralizing antibodies alter the course of HIV-1 infection in vivo. Cell. 2017;170(4):637-648. e610.

117. Richardson BA, Mbori-Ngacha D, Lavreys L, John-Stewart GC, Nduati R, Panteleeff DD, Emery S, Kreiss JK, Overbaugh J. Comparison of human immunodeficiency virus type 1 viral loads in Kenyan women, men, and infants during primary and early infection. J Virol. 2003;77(12):7120-3.

118. Shearer WT, Quinn TC, LaRussa P, Lew JF, Mofenson L, Almy S, Rich K, Handelsman E, Diaz C, Pagano M, et al. Viral load and disease progression in infants infected with human immunodeficiency virus type 1. Women and Infants Transmission Study Group. N Engl J Med. 1997;336(19):1337-42.

119. Wu X, Parast AB, Richardson BA, Nduati R, John-Stewart G, MboriNgacha D, Rainwater SM, Overbaugh J. Neutralization escape variants of human immunodeficiency virus type 1 are transmitted from mother to infant. J Virol. 2006;80(2):835-44.

120. Sanders RW, van Gils MJ, Derking R, Sok D, Ketas TJ, Burger JA, Ozorowski G, Cupo A, Simonich C, Goo L, et al. HIV-1 VACCINES. HIV-1 neutralizing antibodies induced by native-like envelope trimers. Science. 2015;349(6244):4223.
Ready to submit your research? Choose BMC and benefit from:

- fast, convenient online submission

- thorough peer review by experienced researchers in your field

- rapid publication on acceptance

- support for research data, including large and complex data types

- gold Open Access which fosters wider collaboration and increased citations

- maximum visibility for your research: over 100M website views per year

At BMC, research is always in progress.

Learn more biomedcentral.com/submissions 